\title{
Optimizing the Irrigation Water Needs of Lebak Semendawai Swamp in Increasing Agricultural Production
}

\author{
Dinar DA Putranto ${ }^{*}$, Sarino², Agus Yuono ${ }^{3}$, Agus Karsa Yudha ${ }^{4}$ \\ ${ }^{1,2,3}$ Department of Civil Engineering and Planning, Faculty of Engineering, University of Sriwijaya, Indonesia \\ *Email: dinar.dputranto@gmail.com \\ ${ }^{4}$ Department of Public Works, OKU Regency, South Sumatra, Indonesia
}

\begin{abstract}
East OKU Regency, South Sumatra Province, Indonesia, is a region that has great potential in the agriculture and plantation sectors. Utilization of swamps and tidal swamps is used as an alternative to increasing agricultural yields despite extreme changes in river water flow downstream during the dry season.

This study aims to analyze the magnitude of the potential discharge mainstay, and the influence of the magnitude of the flow of the Komering river flow to the availability of water and the availability of optimum discharge in the Lebak Semendawai irrigation area. The total area of 1,218.83 hectares of rice fields, 374.9 hectares is a shallow swamp.

Based on rainfall data for the last ten years, it shows that the potential for discharge is $2.67 \mathrm{~m} 3 / \mathrm{sec}$, while the required water needs is $2.16 \mathrm{m3} / \mathrm{sec}$. (excess water is $0.51 \mathrm{~m} 3 / \mathrm{sec}$ ). The results of the analysis show that the planned cropping patterns that can be applied are Paddy - Paddy - Secondary Crop. The Komering river water discharge which affected the first cropping rice planting pattern was $62.877 \mathrm{~m} 3 / \mathrm{sec}$, the second rice planting period was $43.41 \mathrm{~m} 3 / \mathrm{sec}$ and during the cropping period the water demand could be fulfilled, if it was achieved through pump system with a capacity 1,657.6 liters/sec because the water level of the river from June to November are under the baseline elevation of floodgate on retrieval buildings. Water requirements for the entire irrigation network system in the Lebak Semendawai marsh swamp are $37.22 \mathrm{m3} / \mathrm{sec}$.
\end{abstract}

Keywords - Agricultural, discharge, irrigation, swamp, water level.

\section{INTRODUCTION}

The Indonesian Government's efforts to increase rice productivity include building a swamp irrigation network. Irrigation area of Lebak Semendawai is a rainfed rice field developed by the Indonesian government in South Sumatra Province with an area of approximately 2,244 ha. But in its development, in one year, farmers plant rice between one and two times, but in the second planting season the possibility of failure is more dominant because it has entered the dry season, making it difficult to get water. Water sources are located around the irrigation area. The reliable Lebak Semendawai is the Komering River.

This study aims to analyze the magnitude of potential discharge mainstays in the Lebak Semendawai area, and analyze the magnitude of the Komering river flow discharge to the availability of water as a source of Lebak Semendawai irrigation water, as well as analyze the availability of optimum discharge for the Lebak Semendawai irrigation flow.

\section{METHODOLOGY}

2.1 Research Area

The Lebak Semendawai irrigation area is administratively located in Campang Tiga Ulu village, Sukaraja village and Gunung Jati village, Cempaka District, East OKU Regency, South Sumatra Province with geographical coordinates of east longitude $104^{\circ} 10^{\prime} 1.2^{\prime \prime}$ - 104 $41^{\prime} 49.2^{\prime \prime}$ and $4^{\circ} 27^{\prime} 32.4^{\prime \prime}-4^{\circ} 27^{\prime} 32.4^{\prime \prime}$ south latitude.

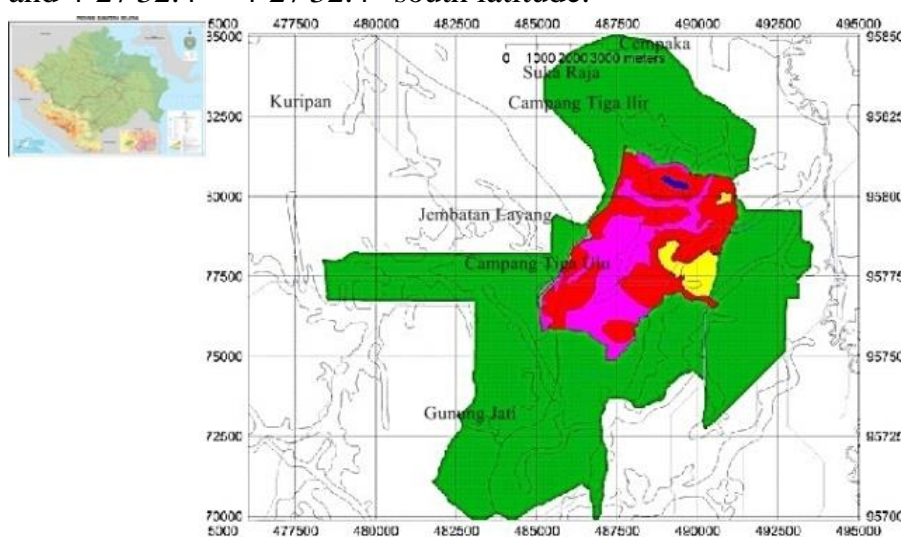

Fig. 1: Lebak Semendawai location area 


\subsection{Research Methods}

To analyze the availability and demand for water resources in the study area, several equations are used to perform calculations

\subsubsection{Rain plan}

Calculation of rain plan is done using several distribution methods, namely the Normal Method, Normal Log, Gumbel, and Pearson Type III log [1]

Normal distribution method,

$$
X_{T}=\mu+K_{T} \cdot \sigma
$$

with

XT : Rain plans with a $\mathrm{T}$ year return period;

$\mu \quad$ : Average values of rain data $(\mathrm{mm})$;

$\sigma \quad$ : Standard deviation.

Normal Log Distribution Method,

$Y_{T}=\bar{Y}+K_{T} \cdot S$

With,

$Y_{T}$ : Estimated value expected to occur with a T-annual return period;

$\bar{Y} \quad$ : The average value of the variate count;

$\mathrm{S} \quad$ : Standard deviation of variate values;

$\mathrm{K}_{\mathrm{T}}$ : Frequency factor.

Pearson Log Type III distribution method,

$\overline{\log X}=\log \bar{X}+\mathrm{G}^{*} \mathrm{~S}$

Gumbel distribution method,

$$
X=\bar{X}+\frac{y_{T}-y_{n}}{S_{n}} \sigma_{n}
$$

With,

$X \quad$ : Extreme value;

$\bar{X} \quad$ : average value;

у $_{\mathrm{T}} \quad$ : reduced variate;

$\mathrm{y}_{\mathrm{n}} \quad$ : reduced variate mean;

$\sigma_{\mathrm{n}} \quad:$ standard deviation

To find an appropriate design, the Chi-Square Test was conducted to test the suitability of the distribution. Chi Square Test $\left(\mathrm{X}^{2}\right)$ was carried out using the following equation,

$X_{\text {count it }}^{2}=\sum_{i=1}^{k} \frac{(F e-F t)^{2}}{F t}$

$X^{2}$ count it : price Chi-Square count it;

Fe $\quad$ : Frequency of observation $\mathrm{j}$ class;

Ft : Frequency of Frekuensi teoritical j class; k : Class Total.

\subsubsection{Calculation of peak discharge}

To design the amount of peak discharge in the study area is carried out using the following approaches,

Nakayasu HSS formula for Flood Peak Discharge,

$Q p=\frac{c \cdot A \cdot R_{O}}{3,6\left(0,3 T p+T_{0,3}\right)}$

with

Qp : Qmaks, is the peak flood discharge (m3 / sec);

c : flow coefficient $(=1)$;

A : Watershed area (until to outlet) $\left(\mathrm{km}^{2}\right)$;

Ro : unit rain $(\mathrm{mm})$;

$\mathrm{Tp}$ : the grace period from the beginning of the rain to the peak of the flood (hours);

While the Rational method function is used to determine the design flood discharge, namely by the equation[2],

$\mathrm{Q}=0,278$ C.I.A (A in ha)

With,

Q : Design flood discharge $\left(\mathrm{m}^{3} / \mathrm{sec}\right)$;

$\mathrm{C}$ : Flow coefficient;

I : rain intensity ( $\mathrm{mm} /$ hour);

A : Watershed area $\left(\mathrm{km}^{2}\right.$ or ha).

While the flood discharge equation according to Haspers [3]

$$
\mathrm{Q}=\alpha . \beta . \mathrm{q} . \mathrm{F}
$$

with,

f : chatment area $\left(\mathrm{km}^{2}\right)$;

$\alpha$ : drainage coefficient;

$\beta$ : reduction coeficient;

q : maximum rainfall $\left(\mathrm{m}^{3} / \mathrm{km}^{2} / \mathrm{sec}\right)$.

And the flood discharge equation according to Mononobe [4]

$$
Q=\frac{\alpha \cdot r \cdot f}{3,6}
$$

With,

$\alpha \quad$ : drainage coefficient;

$\mathrm{r} \quad$ : rainfall intencity $(\mathrm{mm} /$ hour $)$

f : chatment area $\left(\mathrm{km}^{2}\right)$

Q : Flood discharge $\left(\mathrm{m}^{3} / \mathrm{sec}\right)$.

While the flood discharge equation according to Melchior [5] 


$$
Q=\alpha \cdot x \cdot I . x \cdot A \cdot x \cdot \frac{r}{200}
$$

With,

$\mathrm{r}$ : Maximum daily rainfall (mm).

To find out the intensity of rain with a specific period design used the Mononobe method rainfall intensity equation [6]

$$
I=R_{24} / 24[24 / t]^{n}
$$

I :The intensity of rainfall ( $\mathrm{mm} /$ hours);

t : rain concentration time (hours), for Indonesia 5 7 hours;

$\mathrm{R}_{24}$ : maximum rainfall of 1 day ( $\mathrm{mm} /$ hours);

$\mathrm{n}$ : constants (for Indonesia estimated $\mathrm{n} \sim 2 / 3$ ).

Note: the reset factor factor is entered in $\mathrm{R}_{24}$.

\subsubsection{Irrigation Water Needs}

Estimation of irrigation water requirements is carried out by taking into account the guidelines of the Department of Public Works[7],

(1) The need for clean water in the rice fields

$\mathrm{NFR}=\mathrm{Etc}+\mathrm{P}-\mathrm{Re}+\mathrm{WL}$

(2) Irrigation water needs for rice, WRD

$\mathrm{IR}=\mathrm{NFR} / \mathrm{e}$

(3) Need for land preparation for rice

(4) Irrigation water needs for secondary crops, WRP $\mathrm{IR}=(\mathrm{Etc}-\mathrm{Re}) / \mathrm{e}$

Where,

Etc : Consumptive Use;

$\mathrm{P} \quad$ : Water loss due to percolation ( $\mathrm{mm} /$ day);

Re : Effective rainfall (mm/day);

E : Overall irrigation efficiency;

WLR : Water layer replacement (mm/day).

The amount of evapotranspiration is used by the Penman modification method [8]

$\mathrm{ET}=\mathrm{C}[\mathrm{w} \cdot \mathrm{Rn}+(1-\mathrm{w}) \mathrm{f}(\mathrm{U})(\mathrm{ea}-\mathrm{ed})$

With,

ET : Evapotranspiration ( $\mathrm{mm} /$ day);

C : Correction factors due to climate conditions day/ night;

$\mathrm{Rn} \quad$ : Net radiation is equivalent to Evaporation ( $\mathrm{mm} /$ day);

Director General of Irrigation Department of Public Works[9] states that in general water losses in irrigation networks can be grouped into :

( a ) Between $15 \%$ to $22.5 \%$ in tertiary plots, between tertiary tapping buildings and rice fields;

(b) Between $7.5 \%$ to $12.5 \%$ in the secondary channel, and;

(c) Between $7.5 \%$ to $12.5 \%$ in the primary canal.

Calculation of irrigation needs during land preparation can use the method of Van De Goor and Zijlstra[7] (Directorate General of Irrigation Department of Public Works, 1986), namely:

$$
I R=\frac{M e^{k}}{\left(e^{k}-1\right)}
$$

where

IR : Irrigation water needs at the level of rice fields ( $\mathrm{mm} /$ day);

M : Water needs to replace water losses due to evaporation and percolation in saturated fields $\mathrm{M}$ $=\mathrm{Eo}+\mathrm{P}(\mathrm{mm} / \mathrm{day})$

Eo : Open water evaporation taken 1.1 Eto during land preparation ( $\mathrm{mm} /$ day);

P : Percolation;

$\mathrm{k}=\mathrm{MT} / \mathrm{S}$

$\mathrm{T}$ : Time period for land preparation (days);

$\mathrm{S}$ : Water requirements, for saturation are added with a layer of water $50 \mathrm{~mm}$, ie $200+50=250 \mathrm{~mm}$

Consumptive use is calculated using equations [8]

Etc $=\mathrm{Kc}$. Eto

with,

Etc : Plant evapotranspiration (mm/day);

Eto : Reference crop evapotranspiration ( $\mathrm{mm} /$ day);

Kc : Crop coefficient.

The rate of percolation is very dependent on the properties of the soil. In clay soils, with good processing characteristics, percolation rates can reach 1-3 mm/day[10] Effective rain is rainfall that can be effectively utilized by plants. For irrigation in rice plants, monthly effective rainfall is taken $70 \%$ of the average monthly rainfall with a possibility of not meeting $20 \%$

$\operatorname{Re}=0,7 \times R_{80}$

With,

$\mathrm{Re}$ : Effective rainfall (mm/day);

$\mathrm{R}_{80}$ : Mid average monthly rainfall with a $20 \%$ chance of not being met. 
Planting patterns in one year must see the presence or absence of water (water availability) in irrigated areas[11] Conventional discharge measurements can be done by

(1) Determine the wet cross-sectional area of the river (A), i.e. by measuring the estimated water;

(2) Measuring water velocity (V) with a speed meter (current meter) or buoy (the speed is measured with a Stop watch).

Then the discharge calculation (Q) is performed as follows[12]

$\mathrm{A}_{1} \mathrm{~V}_{1} \mathrm{rata}^{2}+\mathrm{A}_{2} \mathrm{~V}_{2} \mathrm{rata}^{2}+\ldots+\mathrm{A}_{\mathrm{n}} \mathrm{V}_{\mathrm{n}} \mathrm{rata}^{2}=\mathrm{Q}$.

with,

Q : River discharge $\left(\mathrm{m}^{3} / \mathrm{sec}\right)$;

$A_{n} \quad$ : N-river cross-sectional area $\left(\mathrm{m}^{2}\right)$;

$\mathrm{V}_{\mathrm{n} \text { rerata }}$ : Average speed on $\mathrm{n}$-cross section $\left(\mathrm{V}_{\text {rerata }}\right.$ point 0,2 $\mathrm{h}$ and $0,8 \mathrm{~h}$ ).

Mainstay debits are debits available throughout the year with a certain risk of failure. Mock introduced a simple model of simulation of monthly water balance for flow which includes rainfall data, evaporation and hydrological characteristics of drainage areas[8]

$\mathrm{Ea}=\mathrm{ETo}-\Delta \mathrm{E} \rightarrow(\mathrm{Ea}=\mathrm{Et})$

$\Delta \mathrm{E}=$ Eto $\times(\mathrm{m} / 20) \times(18-\mathrm{n}) \rightarrow(\mathrm{E}=\Delta \mathrm{E})$

with :

Ea : Actual evapotranspiration (mm/day);

Et : Unlimited Evapotranspiration ( $\mathrm{mm} /$ day);

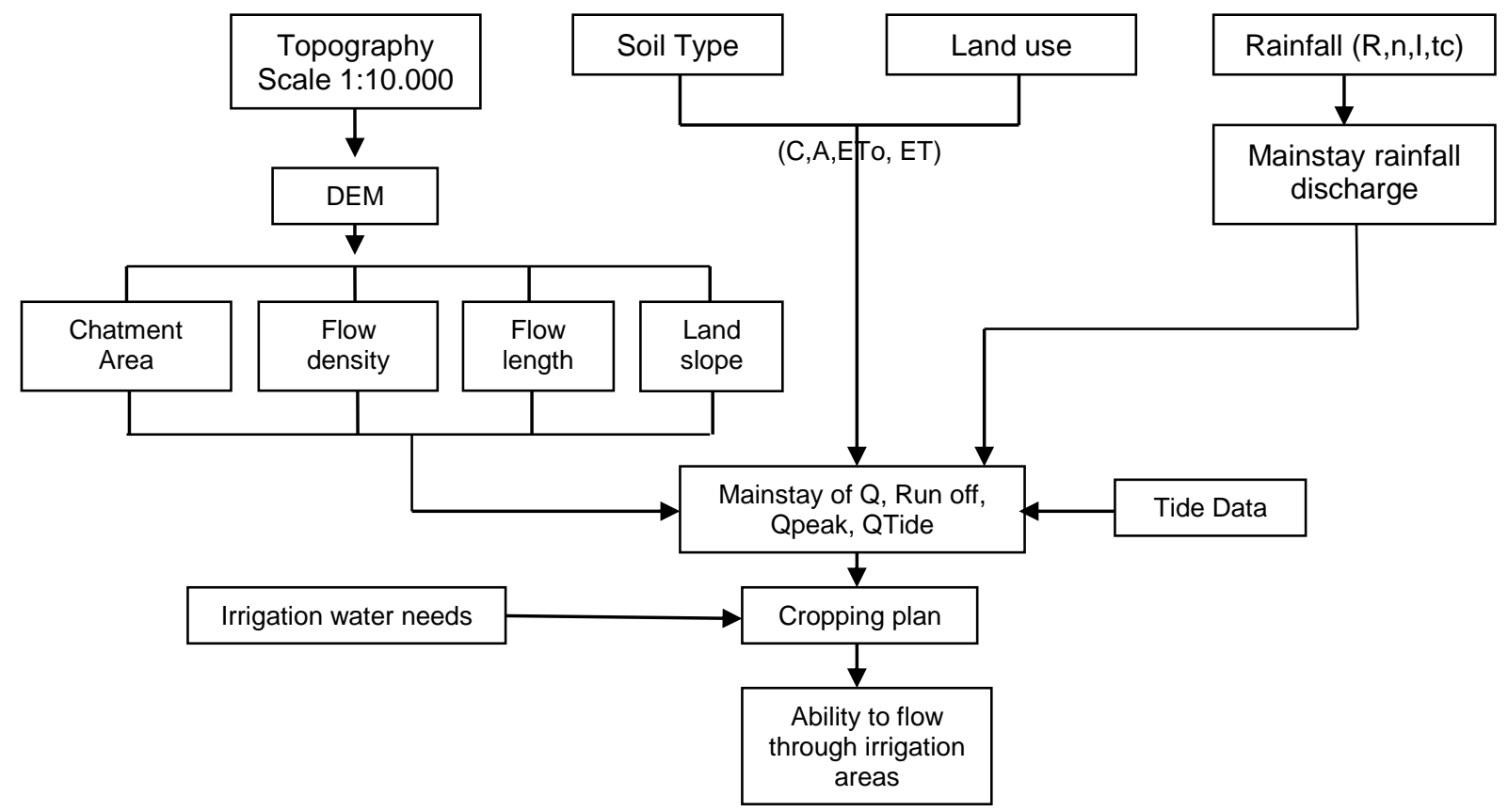

Eto : Potential evaporation of the Penman Method (mm / day);

Basic planning with regard to land units is tertiary plots. These compartments receive irrigation water that is flowed and measured in tertiary off take structures. The secondary plot consists of several tertiary plots, all of which are served by one secondary channel. The primary plot consists of several secondary plots which take water directly from the primary channel.

The discharge plan for a channel is calculated by the formula [11]

$$
Q_{t}=\frac{N F R . A}{1000 . e_{t}}
$$

Where,

$\mathrm{Q}_{\mathrm{t}} \quad$ : Discharge plan $\left(\mathrm{m}^{3} / \mathrm{sec}\right)$;

NFR: The need for clean water in the fields (lt/sec/ha);

A : The area of water is irrigated (ha);

e : Irrigation efficiency in tertiary plots.

Overall efficiency (total) is calculated as follows:

Tertiary network efficiency (et) $\mathrm{x}$ Secondary network efficiency (es) x Primary network efficiency (ep), and between $0.65-0.79$ [7]

Fig. 2: Research flow chart 


\section{RESULTS AND DISCUSSION}

3.1 Data Discharge Input (Inflow)

The initial data sources used in the analysis are rainfall distribution data and Komering river water discharge data. Rainfall data used to forecast rainfall is daily rainfall data for the years 2005 - 2014 obtained from the Seed center Directorate General of Agriculture BK 10 Gumawang Station, East OKU Regency.

The maximum average rainfall between 2005 and 2014 based on Figure 3 below occurred in January of $364 \mathrm{~mm}$ while the minimum rainfall between that year occurred in July and August of $81.1 \mathrm{~mm}$.

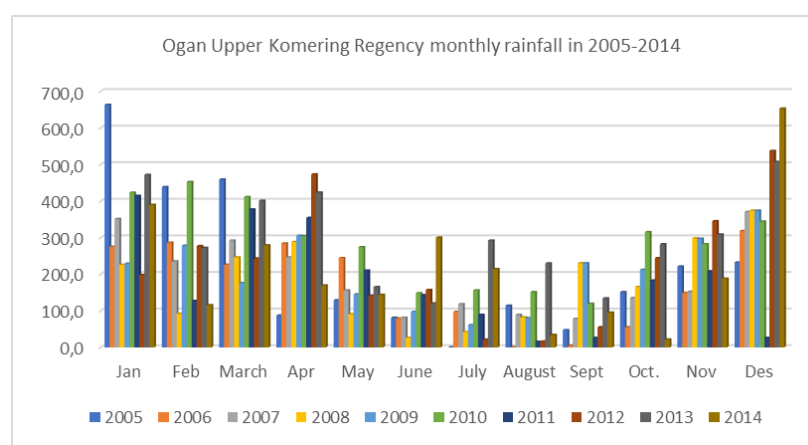

Fig. 3: Monthly maximum rainfall data

\subsection{Plan Rain Analysis}

The return period that will be calculated in each method is the return period of 2, 5, 10, 25, 50 and 100 years. The rainfall data used is the maximum daily rainfall data.

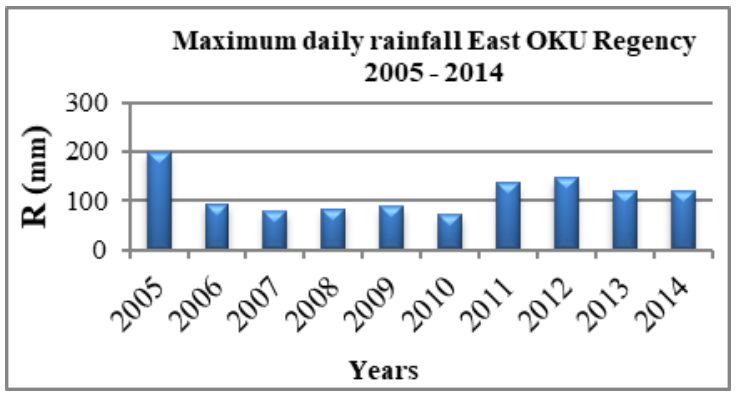

Fig. 4: Maximum daily rainfall data

Figure 4 above provides information that the highest maximum daily rainfall data occurred in 2005 of $199 \mathrm{~mm}$ and the lowest occurred in 2010 of $71 \mathrm{~mm}$.

Table 1. Results of calculated rainfall plans

\begin{tabular}{|c|c|c|c|c|}
\hline \multirow{3}{*}{$\begin{array}{c}\mathbf{T} \\
(\text { Years) }\end{array}$} & \multicolumn{4}{|c|}{ Frequency distribution of rainfall $\mathrm{R}(\mathrm{mm})$} \\
\hline & & Log & Log & \\
\hline & Normal & Normal & Person III & Gumbel \\
\hline 2 & 113,45 & 107,89 & 110,92 & 108,11 \\
\hline 5 & 146,68 & 141,91 & 140,61 & 155,26 \\
\hline 10 & 164,09 & 164,06 & 166,34 & 186,55 \\
\hline
\end{tabular}

\begin{tabular}{ccccc}
25 & 181,02 & 188,79 & 201,37 & 226,04 \\
\hline 50 & 194,54 & 210,86 & 229,62 & 255,36 \\
\hline 100 & 205,62 & 231,21 & 259,42 & 284,44 \\
\hline
\end{tabular}

The rainfall plan $(\mathrm{R})$ in the table above can be displayed in the graph below,

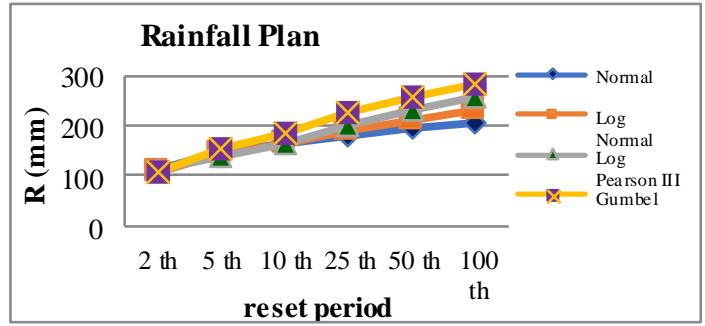

Fig. 5: Rainfall Frequency Distribution

Distribution test results can be seen that the distribution that meets the criteria is the Pearson Log Type III Distribution and Gumbel Distribution.

Table 2. Distribution Test Results

\begin{tabular}{c|cc|c}
\hline $\begin{array}{c}\text { Distribution } \\
\text { Type }\end{array}$ & Terms & Calculation & Conclusion \\
\hline \multirow{2}{*}{ Normal } & $\mathrm{Cs}=0$ & $\mathrm{Cs}=1,125$ & \multirow{2}{*}{ Not meet } \\
\cline { 2 - 3 } & $\mathrm{Ck}=3$ & $\mathrm{Ck}=4,972$ & \\
\hline \multirow{2}{*}{ Log Normal } & $\mathrm{Cs}=3 \mathrm{CV}+(\mathrm{CV} 2)=3$ & $\mathrm{Cs}=0,212$ & \multirow{2}{*}{ Not meet } \\
\cline { 2 - 3 } & $\mathrm{Ck}=5,383$ & $\mathrm{Ck}=3,555$ & \\
\hline Log Person III & $\mathrm{Cs} \neq 0$ & $\mathrm{Cs}=5,536$ & \multirow{2}{*}{ fulfill } \\
\hline \multirow{2}{*}{ Gumbel } & $\mathrm{Cs} \leq 1,396$ & $\mathrm{Cs}=1,125$ & \multirow{2}{*}{ fulfill } \\
\cline { 2 - 3 } & $\mathrm{Ck} \leq 5,4002$ & $\mathrm{Ck}=4,972$ & \\
\hline
\end{tabular}

\subsection{Chi Square Test}

Chi Square Test Results of Pearson Type III Log distribution and Gumbel distribution obtained the parameter Chi-Critical Square $\left(\mathrm{X}^{2} \mathrm{cr}\right)=7.815$ for degrees of freedom $(\mathrm{df})=3$ and the level of confidence $(\alpha)=5 \%$ so that the price of Chi Square is calculated $\left(X^{2}\right.$ count $)=$ 0,4 . Because $X^{2}$ counts are smaller than $X^{2} \mathrm{cr}$, it means that the data corresponds to both distributions. Because the Variance Coefficient $(\mathrm{CV})$ of the Pearson Type III Log distribution is smaller than the Gumbel distribution, the Pearson Type III Log distribution will be used.

\subsection{Mainstay Rainfall}

The rainfall distribution method that can be used from the distribution test results is the Log Pearson III method. The result is obtained a reliable rainfall of $80 \%$ (R80) 183.65 $\mathrm{mm}$. Thus it can be concluded that the $80 \%$ reliability opportunity occurs at a probability of $30 \%$, ie between $180 \mathrm{~mm}$ and $191.9 \mathrm{~mm}$ of rainfall. 


\subsection{Rainfall Intensity}

The intensity of rainfall (I) and daily maximum rainfall $\left(\mathrm{R}_{24}\right)$ of the calculation results can be explained in the graph below,

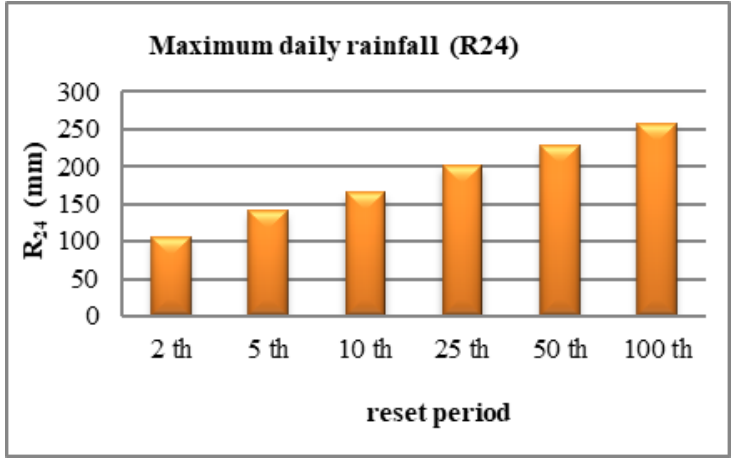

Fig. 6: Daily Maximum Rainfall

The data in Figure 6. above states that for a return period of 2 years the maximum daily rainfall $\left(R_{24}\right)$ is $104.71 \mathrm{~mm}$ and for a 100 year return period of $258.05 \mathrm{~mm}$. The amount of rainfall intensity (I) that is influenced by daily maximum rainfall $\left(\mathrm{R}_{24}\right)$ can be seen in the graph below

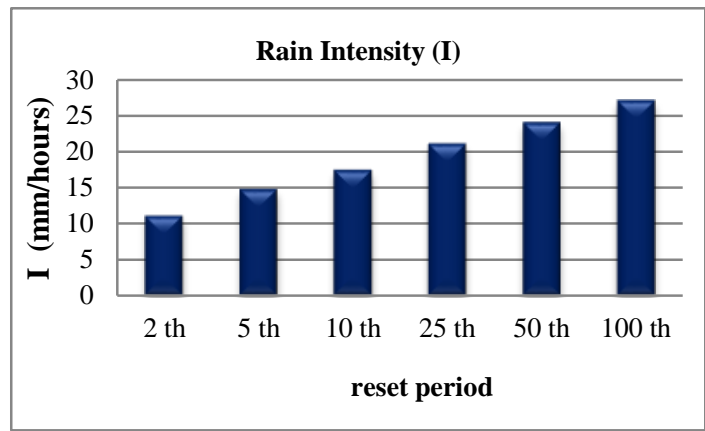

Fig. 7: Intensity of rainfall Mononobe method

The intensity of rainfall (I) that occurred in the 2-year return period is shown in Figure 6 above $10.994 \mathrm{~mm} /$ hour and the 100-year return period of 27,093 mm/hour. 3.6. Mainstay Discharge

Analysis of rainfall with the probability method is known that rainfall data and the number of rainy days $(\mathrm{HH})$ that can be used is rainfall data in 2008. From the calculation results obtained by the reliable discharge as follows

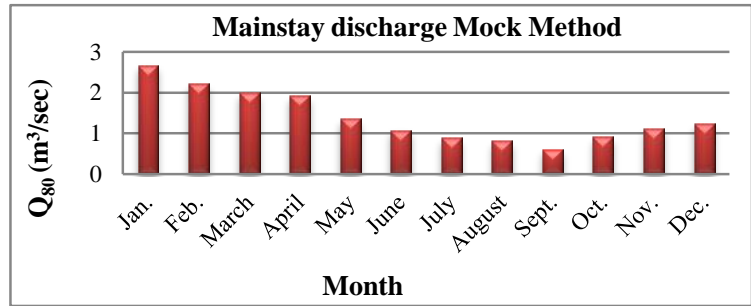

Fig. 8: Mainstay Discharge Method F.J. Mock
The magnitude of the mainstay discharge stated in Figure 8 above is the highest mainstay discharge occurred in January which is $2.67 \mathrm{~m}^{3} / \mathrm{sec}$ and the lowest occurred in September of $0.61 \mathrm{~m}^{3} / \mathrm{sec}$. This means that the decline in reliability occurs from January to September.

\subsection{Nakayasu Synthetic Hydrograph Unit}

The results of the calculation of the Nakayasu Synthetic Hydrograph can be obtained from the magnitude of flood discharges of the return period of 2 years to 100 years.

The Nakayasu method flood discharge at Table 3 can be outlined in the form of a hydrograph model shown in the following Figure 9,

Table 3. Nakayasu Method Flood Peak Discharge

\begin{tabular}{|l|l|}
\hline $\begin{array}{l}\text { Re Period } \\
\text { T (years) }\end{array}$ & $\begin{array}{l}\text { Flood peak discharge } \\
\left(\mathrm{m}^{3} / \mathrm{sec}\right)\end{array}$ \\
\hline 2 & 200,974 \\
5 & 269,489 \\
10 & 318,290 \\
25 & 385,200 \\
50 & 438,759 \\
100 & 495,500 \\
\hline
\end{tabular}

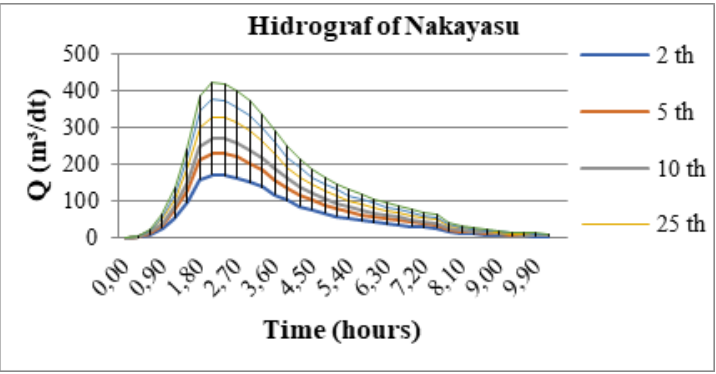

Fig. 9: Nakayasu Synthetic Hydrograph Lebak Semendawai irrigation

\subsection{Flood Peak Discharge}

Calculation of peak discharge (Qp) with the Rational method obtained through spatial analysis can be displayed in the figure below

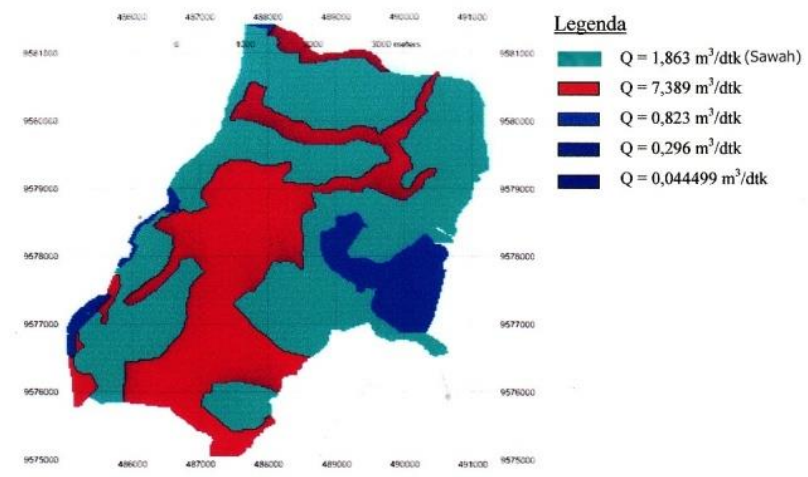

Fig. 10: Peak Discharge (Qp) Rational method

Data processing from the spatial analysis results above shows that the highest peak discharge (Qp) at the location 
of the study was $7.389 \mathrm{~m}^{3} / \mathrm{s}$ and the lowest was 0.044499 $\mathrm{m}^{3} / \mathrm{s}$. The total peak discharge (Qp tot) that occurred was $10,415 \mathrm{~m} 3 / \mathrm{sec}$.

\subsection{Peak Flood Discharge Plan with the Empirical Method}

The calculation of flood discharge plan is calculated by empirical methods including Haspers, Mononobe and Melchior methods, the following results are obtained.

Table 4. Recapitulation of Flood Hydrograph Calculation Results for Empirical Method Planning

\begin{tabular}{|l|l|l|l|}
\hline \multirow{2}{*}{ Period } & \multicolumn{3}{|l|}{ flood discharge $(\mathrm{Q})\left(\mathrm{m}^{3} / \mathrm{sec}\right)$} \\
\cline { 2 - 4 } (years) & Haspers & Mononobe & Melchior \\
\hline 2 & 97,066 & 64,187 & 71,417 \\
5 & 130,040 & 85,992 & 95,678 \\
10 & 153,669 & 101,617 & 113,063 \\
25 & 185,947 & 122,962 & 136,812 \\
50 & 211,829 & 140,077 & 155,855 \\
100 & 239,212 & 158,185 & 176,003 \\
\hline
\end{tabular}

Flood discharge (Q) Empirical method in Table 4. above can be poured into the following graph

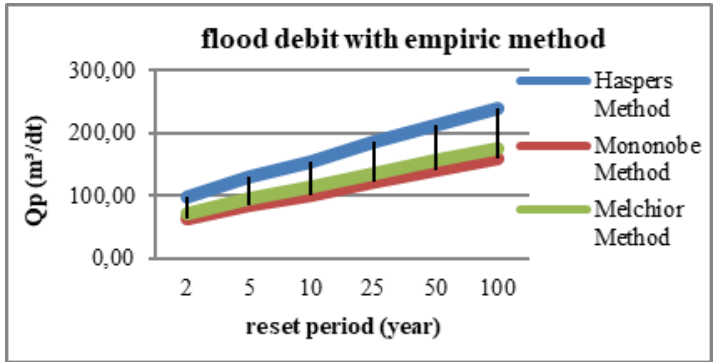

Fig. 11: Flood Hydrograph of the Empirical Method Plan

3.10 Irrigation Water Needs Analysis

3.10.1 Evapotranspiration of the Penman Method

Calculation of potential Evapotranspiration (ETo) with the Penman method obtained the following results

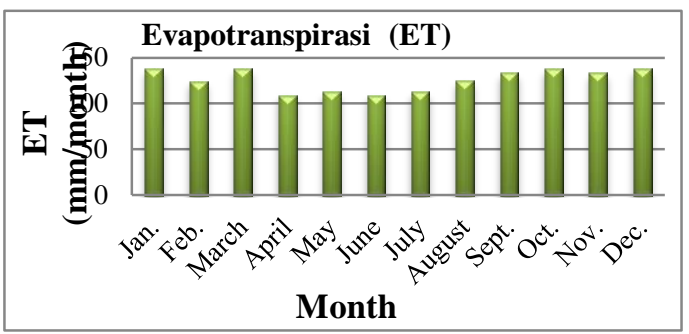

Fig. 12: Evapotranspiration of the Modified Penman Method

Figure 12 above explains that the highest Evapotranspiration occurred in January, March, October and December amounted to $137.90 \mathrm{~mm} / \mathrm{month}$ and the lowest occurred in April and June amounted to 109.19 $\mathrm{mm} / \mathrm{month}$. The amount of Evapotranspiration (ET) based on land use can be shown in the following graph.

The highest evapotranspiration based on Figure 13. The follow occurred in the cocoa area which was 1.42 $\mathrm{mm} /$ day and the lowest occurred in the rice field area 0.20 $\mathrm{mm} /$ day. This shows that evapotranspiration in paddy fields is lower than other areas

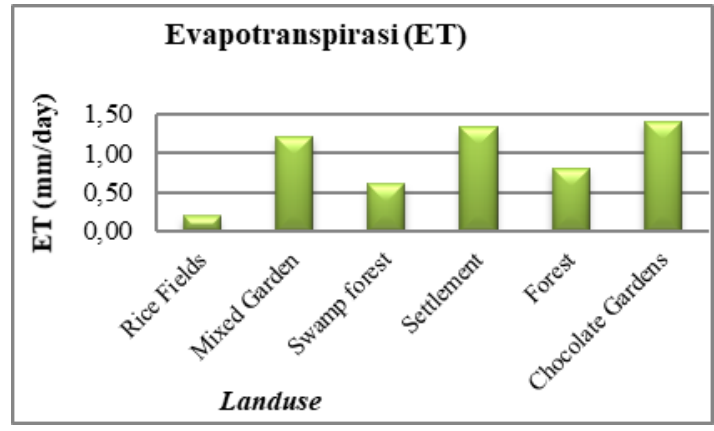

Fig. 13: Evapotranspiration based on Land Use Maps

\subsubsection{Percolation}

The rate of percolation is very dependent on the properties of the soil. The percolation rate used is 2 $\mathrm{mm} /$ day with consideration of soil texture in the location area

3.10.3 Effective rainfall for rice and secondary crop water needs

The probability in determining how much the reliability of the flow is applied using the basic year method. The results of these methods obtained by reliable rainfall of rice plants $\left(\mathrm{R}_{80}\right)$ using rainfall data in 2011 and reliable crops of crops $\left(\mathrm{R}_{50}\right)$ using rainfall data in 2014.

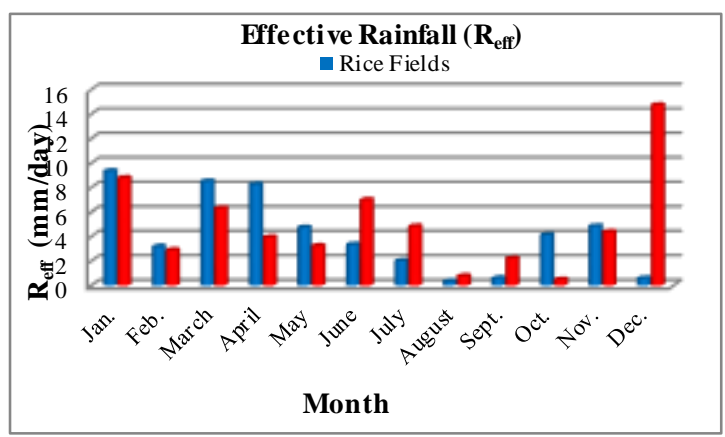

Fig. 14: Effective rainfall of rice and secondary crops

Maximum effective rainfall (Reff) for rice analysis results Figure 14 above is estimated to occur in January which is $9.35 \mathrm{~mm}$ day and the maximum reff for secondary crop occurs in December amounted to $14.74 \mathrm{~mm} /$ day. 
3.10.4 Irrigation Efficiency

The guideline used for irrigation efficiency planning in operation and implementation, namely water loss in Tertiary plots is determined $20 \%$ between tertiary tapping buildings and paddy fields with an efficiency factor of 1.25. In the Secondary Channels is determined $10 \%$ with an efficiency factor of 1.11 and for the Primary Channels is determined $10 \%$ with an efficiency factor of 1.11 .

\subsubsection{Irrigation Water Needs and Planting Patterns}

Irrigation water needs include crop water needs per irrigated land area. Planting patterns that can be applied from the analysis of irrigation water needs are Rice - Rice - Secondary Crop with the provisions that the Rice planting period lasts for 4.5 months, Rice planting period for 4 months and crops for 3.5 months. The results of the analysis of the calculation of Irrigation Water Needs for an area of $1,218.83 \mathrm{Ha}$ can be displayed in the graph below

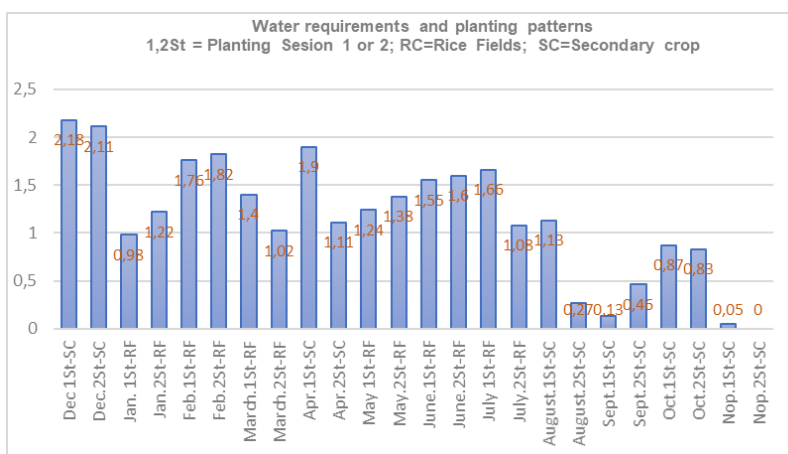

Fig.15: Irrigation Water Needs and Planting Pattern Plans

The amount of maximum irrigation water requirements for the 1st planting season for $1,218.83 \mathrm{Ha}$ as shown in Figure 15 above is $2.18 \mathrm{lt} / \mathrm{sec} / \mathrm{ha}$ at the beginning of December, the 2nd planting period $1.90 \mathrm{lt} / \mathrm{sec} / \mathrm{ha}$ in early April and secondary crop at $1.13 \mathrm{lt} / \mathrm{sec} / \mathrm{ha}$ in early August

\subsection{River Water Discharge Based on Comparison of} Rainfall Occurred

River water discharge $(\mathrm{Q})$ when rainfall is low in October 2014 results of measurements of river flow velocity using Current meters and river cross section using Echosounder is $25.30 \mathrm{~m}^{3} / \mathrm{sec}$. River water discharge (Q) during moderate rainfall of $219.97 \mathrm{~m}^{3} / \mathrm{sec}$ is obtained based on the ratio of river water discharge and rainfall that occurs when rainfall is low in October with moderate rainfall in November.

The results of comparison of river water discharge and low rainfall in October with the prediction of high rainfall in January obtained river water flow (Q) when high rainfall amounted to $426.35 \mathrm{~m}^{3} / \mathrm{sec}$.
3.12 Potential Use of the Komering River as a source of Lebak Semendawai Irrigation Water

3.12.1. Water Levels Based On Water Level Fluctuations The results of data processing of water level fluctuations show that the average water level is $1.156 \mathrm{~m}$, the highest high tide is $1.65 \mathrm{~m}$ and the lowest low tide is $0.75 \mathrm{~m}$. Fluctuations that occur are mixed tides $(0.25<\mathrm{F}<3.00)$ based on the Formzahl value $\mathrm{F}=1.18$ above. Of the two types of mixed tides, the tides that occur are the mixeddominant diurnal tides for $0.50<\mathrm{F} \leq 3.00$.

3.12.2 River water discharge based on prediction of high fluctuations in water

River water discharge is obtained from the multiplication between the total river cross-sectional area (A) and the river flow velocity $(\mathrm{V})$. The measurement results using Echosounder and Current Meter as well as water level from river water level fluctuation data can be seen that,

(1) Based on the average height of low water level over a period of 19 years (MLWL) $0.59 \mathrm{~m}$, obtained river water flow $(\mathrm{Q})$ when rainfall is low at $24.37 \mathrm{~m} 3 / \mathrm{sec}$;

(2) Based on the average height of the high water level over a period of 19 years (MHWL) $1.57 \mathrm{~m}$, the river water flow obtained during moderate rainfall was $144.7 \mathrm{~m} 3 / \mathrm{sec}$

(3) Based on the highest water level at the tidal full moon (HHWL) $1.86 \mathrm{~m}$, river water discharge obtained during high rainfall amounted to $209.59 \mathrm{~m} 3 / \mathrm{sec}$;

3.12.3 Prediction of availability of average river water discharge per month based on fluctuations in surface water and rainfall occurred

The average river water discharge (Qrt) per month can be displayed in the following graph

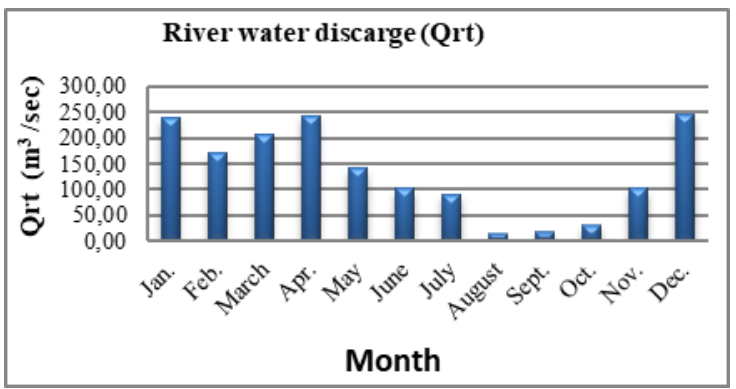

Fig. 16: Monthly river water discharge (Qrt)

The highest average river water flow (Qrt) based on Figure 16 above occurred in December, which was $246.60 \mathrm{~m} 3 / \mathrm{s}$ and the lowest occurred in August 14.36 $\mathrm{m}^{3} / \mathrm{s}$. The predicted results of the average water level per month can be displayed in the following table 
Table 5. Monthly Average River Water Level

\begin{tabular}{lc}
\hline Month & Average Water Level (m) \\
\hline Jan. & 2,60 \\
\hline Feb. & 1,84 \\
\hline Marc. & 2,23 \\
\hline Apr. & 2,65 \\
\hline May & 1,53 \\
\hline June & 1,11 \\
\hline July & 0,98 \\
\hline Aug. & 0,16 \\
\hline Sept. & 0,20 \\
\hline Oct. & 0,34 \\
\hline Nov. & 1,11 \\
\hline Dec. & 2,67 \\
\hline
\end{tabular}

The water level above when connected to the condition of the building intake (free intake) can be shown in the following figure

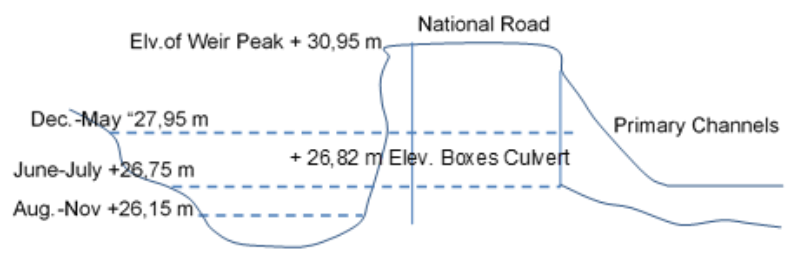

Fig. 17: Average River Water Level against Free Intake Conditions

River water discharge in June - July and August November based on Figure 16 above has an average water level of $1.05 \mathrm{~m}$ and $0.45 \mathrm{~m}$ from the bottom of the river under the elevation of the Box Culvert base so as to be able to drain the irrigation water source to the location Paddy fields cannot use box culvert channels to drain water, so a pump system is needed.

\subsection{Water Discharge Irrigation Network System}

How much water flow $(\mathrm{Q})$ needed to irrigate the irrigation network must be analyzed

3.13.1 Water availability per month based on planned water needs and cropping patterns

How much water flow $(\mathrm{Q})$ needed to irrigate the irrigation network must be analyzed how big is the availability of water available, compared with the required water debit. The results of the calculation of water discharge (Q) needed based on the analysis that has been done is 37.220 $\mathrm{m} 3 / \mathrm{sec}$. to flow through $1271.69 \mathrm{Ha}$ of paddy fields.

(a) Paddy planting season 1 (end of November - March when rainfall is high)
River water discharge during high rainfall $209.59 \mathrm{~m}^{3}$ /sec; Availability of river water at the intake for irrigation $103.57 \mathrm{~m} 3 / \mathrm{sec}$; Peak water discharge on the surface $10,415 \mathrm{~m} 3 / \mathrm{sec}$; availability of water for irrigation $(30 \% \times 209.59)+(70 \% \times 10,415)=70.17$ $\mathrm{m} 3 / \mathrm{sec}$;

(b) 2nd planting season (April - July during moderate rainfall)

River water discharge during moderate rainfall $144.70 \mathrm{~m}^{3} / \mathrm{sec}$; Availability of river water at the intake for irrigation $38.68 \mathrm{~m} 3 / \mathrm{sec}$; Water discharge rivers for irrigation in June and July $(-3.48 \mathrm{~m} 3 / \mathrm{sec}$ and $-15.3 \mathrm{~m} 3 / \mathrm{sec}$ ) are met if pumping with a capacity of $1657.6 \mathrm{lt} / \mathrm{sec}$; Peak water discharge on the surface $5,705 \mathrm{~m} 3 / \mathrm{sec}$; availability of water for irrigation $(30 \% \times 144.70)+(70 \% \times 5.705)=47.40 \mathrm{~m} 3 / \mathrm{sec}$;

(c) Secondary crop (August - early November when rainfall is low)

River water discharge when rainfall is low $24.37 \mathrm{~m}^{3}$ / $\mathrm{sec}$; Availability of river water for irrigation does not exist $-81.65 \mathrm{~m} 3 / \mathrm{sec}$ (Qintake $=0.00 \mathrm{~m} 3 / \mathrm{sec}$ ); River water discharge for irrigation is fulfilled if the pump capacity is $1,657.6 \mathrm{lt} / \mathrm{sec}$; River water discharge for pumping irrigation resulting from 7,311 m3/sec; Peak water discharge at $4,517 \mathrm{~m} 3 / \mathrm{sec}$; Water supply for irrigation is $11,828 \mathrm{~m} 3 / \mathrm{sec}(7,311 \mathrm{~m} 3 / \mathrm{sec}+4,517$ $\mathrm{m} 3 / \mathrm{sec})$.

3.13.2 Excess water in the swamp area and adjustment of the planting pattern plan

The plan to prepare land in swampy swamp area for planting rice 1 is strongly influenced by excess water in the area because it is not possible to plant if the amount of water is too excessive. The excess water for the 1st planting season rice in the swampy swamp areas above based on the analysis of water availability in the plot can be shown in the following table

Table 6. Excess water in the plot and water discharge plots in the swamp area based on water availability for the 1st Planting Rice

\begin{tabular}{|l|c|c|}
\hline Rice Fields & $\begin{array}{c}\text { Excess water plot plan } \\
(\mathbf{m} 3 / \mathbf{s e c})\end{array}$ & $\begin{array}{c}\text { Swamp water } \\
\text { discharge }(\mathbf{m} 3 \mathbf{s e c})\end{array}$ \\
\hline CT4-Ka & 0,268 & 0,232 \\
\hline CT4-Tg & 0,177 & 0,286 \\
\hline C1-Ki & 0,180 & 0,169 \\
\hline C2-Ki & 0,191 & 0,239 \\
\hline C3-Ki & 0,194 & 0,282 \\
\hline C3-Ka & 0,199 & 0,235 \\
\hline Lb.4-Ki & 0,136 & 0,194 \\
\hline Lb.4-Ka & 0,264 & 0,293 \\
\hline Lb.3-Ka & 0,180 & 0,225 \\
\hline Lb.3-Ki & 0,077 & 0,071 \\
\hline Total & 1,866 & 2,226 \\
\hline
\end{tabular}


The excess water in the planned plot of swampy swamp area according to Table 6 above is $1.866 \mathrm{~m} 3$ / sec (161.222.4 m3 / day). Water discharge in the swampy swamp area is 2,226 m3 / sec (192,326.4 m3 / day) with a swampy swamp area of $374.9 \mathrm{Ha}$ of the total planned plot of 663.05 ha. The water discharge is predicted to occur at the highest rainfall in December. Thus, monthly water discharge in the swampy swamp area based on comparison of the average rainfall that occurs can be displayed in the following table

Table 7. Prediction of water discharge in the swamp area per month

\begin{tabular}{lc} 
& $\begin{array}{c}\text { Wer month } \\
\text { Swampy area } \\
\text { Month }\end{array}$ \\
\hline Jan. & 2,169 \\
\hline Feb. & 1,534 \\
\hline Marc. & 1,854 \\
\hline Apr. & 1,748 \\
\hline May & 1,013 \\
\hline June & 0,734 \\
\hline July & 0,649 \\
\hline Aug. & 0,483 \\
\hline Sept. & 0,607 \\
\hline Oct. & 1,051 \\
\hline Nov. & 1,459 \\
\hline Dec. & 2,226 \\
\hline
\end{tabular}

The highest prediction of swamp water discharge based on Table 7 above occurred in December, which was 2.226 $\mathrm{m} 3 / \mathrm{sec}(192,326.4 \mathrm{~m} 3 /$ day $)$ and the lowest in August was $0.483 \mathrm{~m} 3 / \mathrm{sec}(41,731.2 \mathrm{~m} 3 /$ day $)$. Planting patterns that can be applied to the swampy swamp area are based on the above water discharge, namely:

(1) The first cropping season in October - February;

(2) The 2nd cropping season in March - early June;

(3) Secondary crop at the end of June - September.

The cropping plan for the 1st planting season is planted with special local species, namely surung rice (alabio, tapus, nagara and hiyang) because the water discharge is still quite high. For the second planting season rice can be planted with rice types in Indonesia (IR 42, IR 64, IR 66, and local species as Cisokan, Ciherang, Cisanggarung and Mekonga rice types). Secondary crop can be planted with a mound system (elevated section). Rice fields in the form of rice fields in general (not swamp) can follow the previous cropping plan, namely:

(1) The first cropping season at the end of November March;
(2) Rice planting period 2 in April - July;

(3) Secondary crop in August - early November.

\section{CONCLUSIONS AND RECOMMENDATIONS}

4.1 Conclusions

(1) Potential magnitude of mainstay discharge based on the swamb area based on the flowing pattern limit in the Lebak Semendawai area which is affected by the Komering River is $2.67 \mathrm{~m}^{3} / \mathrm{sec}$ with the required water demand of $2.16 \mathrm{~m}^{3} / \mathrm{sec}$ so that there is excess water (water surplus) of $0,51 \mathrm{~m}^{3} / \mathrm{sec}$ (sufficient);

(2) The magnitude of the influence of river water discharge is able to support the availability of water for irrigation activities based on the planned Rice Rice - secondary crop cropping pattern, namely:

(a) The 1st planting season (end of November March) takes place during high rainfall, river water discharge $(30 \%)$ which can be used for irrigation of $62,877 \mathrm{~m} 3 / \mathrm{sec}$;

(b) The 2nd planting season (April - July) takes place during moderate rainfall, river water discharge (30\%) which can be used for irrigation of 43.41 $\mathrm{m} 3 / \mathrm{sec}$ with the irrigation network water requirement of $32.62 \mathrm{~m} 3 / \mathrm{sec}$ (sufficient). Irrigation network water needs in June and July can be fulfilled if a pumping system with a pump capacity of $1657.6 \mathrm{lt} / \mathrm{sec}$ is implemented, given the river water discharge is below the elevation of the floodgate;

(c) Secondary crop (August - Early November) takes place when rainfall is low, river water discharge that can be used for irrigation is absent $(-81.65$ $\mathrm{m} 3 / \mathrm{sec}$ below the elevation of the floodgate at the intake). Surface water discharge is $4,517 \mathrm{~m} 3 / \mathrm{s}$. Irrigation system water needs can be met if pumping is carried out with a pump capacity of $1,657.6 \mathrm{lt} / \mathrm{sec}$ so that $30 \%$ of river water debit obtained is $7,311 \mathrm{~m} 3 / \mathrm{sec}$. Thus the crop water needs are fulfilled $(7,311 \mathrm{~m} 3 / \mathrm{sec}>3.74 \mathrm{~m} 3 / \mathrm{sec})$.

(3) The amount of optimum availability of Lebak Semendawai Irrigation is:

(a) Paddy planting period 1 availability of optimum discharge is $70.17 \mathrm{~m} 3 / \mathrm{sec}$. The availability of water in the plot of rice for $6,472 \mathrm{~m} 3 / \mathrm{sec}$ with plant water needs $2,167 \mathrm{~m} 3 / \mathrm{sec}$;

(b) In the 2nd planting period, the optimum discharge availability is $47.40 \mathrm{~m} 3 / \mathrm{sec}$. The availability of water in the planned plot of rice is $5,027 \mathrm{~m} 3 / \mathrm{sec}$ with plant water needs $1,897 \mathrm{~m} 3 / \mathrm{sec}$;

(c) the availability of optimum discharge Secondary crop $11,828 \mathrm{~m} 3 / \mathrm{sec}$. Availability of water in 
planned plots for secondary crop $1,817 \mathrm{~m} 3 / \mathrm{sec}$ with plant water needs $1,128 \mathrm{~m} 3 / \mathrm{sec}$.

\subsection{Recommendations}

Further research is needed regarding the efficiency and economic value of the use of pumps to irrigate the irrigation network system

\section{ACKNOWLEDGEMENTS}

Acknowledgments were conveyed to the Research and Community Service Institute of the University of Sriwijaya University, which provided research funding for Higher Education Competitive Grants based on Agreement / Contract 0149.032 / UN9 / SB3.LP2M.PT / 2019 with the chairman of LPPM, on 27 June 2019

\section{REFERENCES}

[1] Oregon State University, "Analysis Techniques: Flood Analysis Example with Daily Data ( Log-Perason Type III Distribution )," Streamflow Eval. watershed Restor. Plan. Des., pp. 2002-2005, 2005.

[2] S. Stanchi et al., "Soil erosion in an avalanche release site (Valle d'Aosta: Italy): Towards a winter factor for RUSLE in the Alps," Nat. Hazards Earth Syst. Sci., 2014.

[3] A. Jordán et al., "Wettability of ash conditions splash erosion and runoff rates in the post-fire," Sci. Total Environ., vol. 572, 2016.

[4] D. D. Prayuda, "Temporal and spatial analysis of extreme rainfall on the slope area of Mt. Merapi," Civ. Eng. Forum, vol. XXI, no. September, pp. 1285-1290, 2012.

[5] C. A. Bana e Costa, P. Antão da Silva, and F. Nunes Correia, Multicriteria evaluation of flood control measures: The case of Ribeira do Livramento, vol. 18, no. 3. 2004.

[6] J. Liu, W. Liu, and K. Zhu, "Throughfall kinetic energy and its spatial characteristics under rubber-based agroforestry systems," Catena, vol. 161, 2018.

[7] Department of Public Works, > SPECIFICATIONS For : I STANDARD, no. September. 1986.

[8] A. Amazirh et al., "Modified Penman-Monteith equation for monitoring evapotranspiration of wheat crop: Relationship between the surface resistance and remotely sensed stress index," Biosyst. Eng., vol. 164, no. September, pp. 68-84, 2017.

[9] P. Panagos et al., "The new assessment of soil loss by water erosion in Europe," Environ. Sci. Policy, vol. 54, 2015.

[10] C. D. Cheng, S. J. Cheng, J. C. Wen, and J. H. Lee, "Time and flow characteristics of component hydrographs related to rainfall-streamflow observations," J. Hydrol. Eng., vol. 18, no. 6, pp. 675-688, 2013.

[11] S. Ali et al., "Planting patterns and deficit irrigation strategies to improve wheat production and water use efficiency under simulated rainfall conditions," Front. Plant Sci., vol. 8, no. August, 2017.
[12] S. Sulianto, M. Bisri, L. Limantara, and D. Sisinggih, "Performance of The Dispin Models with Automatic Parameter Calibration on The Transformation of Rainfall to Runoff Data," Civ. Environ. Sci., vol. 002, no. 02, pp. 084-094, 2019. 